\title{
Máté Julesz': The New Hungarian Constitution (Basic Law) of 2011 and Environmental Protection
}

Debreceni Jogi Mühely, 2012. évi (IX. évfolyam) 2. szám (2012. április) 36-38.

\section{Introductory Comments}

Hungary has been on the way of environmentalism not solely in the post-communist era, but already from the beginning of the 1970s, parallelly to the 'environmental decade' in the United States and to western democracies. The 'environmental decade' launched by US President Nixon had an impact on Eastern European communist countries. Environmentalism was not a civil society movement, since there was not any civil society in the communist countries. Society was included in the state. A state environmental policy allowed legal theoreticians to travel abroad and also to import a restricted level of environmentalism. In the 1970s and 1980s, environmental legal theoreticians layed down the fundaments of environmental protection, and later, those of a sustainable development. A number of rules of environmental jus naturale were legislated. Those first environmental legal norms have since undergone recodifications.

\section{Environmental Axiology of the New Constitution of Hungary}

During the history of Hungary, several constitutions were proclaimed. The constitution of 1949, called Stalinian constitution, was entirely reformed pro primo in 1972, pro secundo in 1989/1990. The new constitution of Hungary was proclaimed on April 25, 2011 and it is to come into effect on January 1, 2012. The constitution is, after German example, codified as the 'basic law of Hungary'. In the current saying, it is also called the constitution of Easter, since it was proclaimed on Easter Monday (April 25, 2011). In contrast to the previous constitution, it contains four major parts:

- Preamble,

- Basic Stipulations,

- Freedom and Responsibility,

- $\quad$ and The State.

Article P) of the Basic Stipulations says that 'natural resources, especially arable land and the drinking water supplies, as well as the biological diversity, especially species of plants and animals, and cultural values, which all form part of the common national heritage, are to be preserved for future generations by the state and by all others'. The new basic law declares that the right to environment is not solely a right, but also as an obligation. From this approach, the new basic law differs much from the precedent one.

Axiologically, the Basic Stipulations are a catalogue of national values. In environmental matter, the true changes are to be found under Freedom and Responsibility. In this part of the basic law, rights and obligations are constitutionalized. Paragraph (1) of Article XX of the new basic law declares that 'everyone has the right to physical and mental health'. A similar declaration was to be found in the former constitution of Hungary, though not only from 1989/1990, but already from 1972. According to the texts of present and previous constitutions, Hungary is not an eco-social market economy, however, de facto et de jure, Hungary follows a way to become an eco-social market economy. A parallel, finally not adopted draft constitution contained the notion of eco-social market economy, copying the theory developed by Austrian politician Joseph Riegler during the 1980s. 


\section{The Basic Right to a Healthy Environment}

The right to physical and mental health is detailed in Paragraph (2) of Article XX of the new basic law of Hungary. The jura servilia of the right to health are deployed in Paragraph (2):

- GMO-free agriculture,

- the right to food and water supply,

- the right to work health and safety and to medical care,

- the right to professional and amateur sports,

- and environmental protection.

A GMO-free agriculture, as a constitutional objective value, generated debate among green activists, representatives of the parliamentary green party, scientists, lawyers and philosophers. Many criticisms focused on the question: Does Hungary really need to be a GMO-free country? In Ecuador, we may find a similar stipulation in the constitution of 2008. In the long run, the status of GMO-free country could certainly yield profit to Hungary, though it would be difficult to really keep Hungary away from genetically modified organisms. Contaminations have already been reported from several parts of the country. Subparagraph (a) of Paragraph 2 of Article 11 of the International Covenant on Economic, Social and Cultural Rights says that the reformation of agrarian systems should happen in such a way as to achieve the most efficient development and utilization of natural resources. Food and water supply is a human right that was missing from the former constitution. Other human rights, such as clothing, are still missing from the new basic law. The right to work health and safety and to medical care is also a human right that was already to be found in the former constitution. The right to sports is a new constitutional right, since only the right to amateur sports was implied in the former constitution which is, according to Paragraph (2) and Paragraph (4) of Article 1 of the Act on Sports, not the same as professional sports.

Environmental protection comes at last, however, it is detailed in the following Article. Paragraph (1) of Article XXI says that 'everyone has the right to a healthy environment'. According to Paragraph (2) of the same Article, everyone who causes damage to the environment is to clean up or pay for cleanup costs. Paragraph (3) of the same Article says that 'it is forbidden to import waste into Hungary in order to dispose of it. Environmental protection is an objective value of all citizens and non-citizens being in Hungary. It could be a global objective value if codified in every country of the globe. The right to a healthy environment is a human right of third generation of human rights. The new basic law of Hungary brought reforms to the Articles on environmental protection of the former constitution in a way to conform to environmental protection at EU level: Paragraphs (2) and (3) of Article XXI were conceived up to relevant EU directives and regulations.

\section{A Limited Level of Environmental Nationalism}

The Preamble, called 'National Confession of Faith', of the new Hungarian basic law says that 'the members of the Hungarian nation bear responsibility for their descendants and protect their material, spiritual and natural resources, insofar as it is in the interest of the next generations'. It is also declared that 'the members of the Hungarian nation protect the natural and civilizational values of the Carpathian Basin'. This latter declaration provides the new Hungarian basic law with a certain extraterritorial effect. A similar extraterritoriality has already been codified in the Act on Nature Conservation of 1996. In environmental law, a certain degree of extraterritoriality seems to be admitted by the whole of the nation. This nationalism is, of course, to be kept within the scope of nature conservation. Regarding 
relationship between neighbouring Eastern European countries, environmental injustice, if it ever occurs, would be a tender spot.

From the aspect of social ecology, the new Hungarian basic law reflects social and economic changes in recent Eastern European history. The ontology of social existence has brought new objective values to environmental constitutional law, moreover, economic activities by individuals supplied environmental constitutionality with subjective values.

A limited level of environmental nationalism is accepted all over the world. When it is about nature conservation, protection of biodiversity, reduction of greenhouse gas emission, or similar global priorities, the rule of law can provide the justifications. Paragraph 2 of Article 1 of the International Covenant on Economic, Social and Cultural Rights says: 'All peoples may, for their own ends, freely dispose of their natural wealth and resources without prejudice to any obligations arising out of international economic co-operation, based upon the principle of mutual benefit, and international law. In no case may a people be deprived of its own means of subsistence.' According to Article 25, 'nothing in the present Covenant shall be interpreted as impairing the inherent right of all peoples to enjoy and utilize freely their natural wealth and resources'. When ethnic minorities are involved in environmental injustice, democratic states and societies have to consider the triple value of 'freedom, justice and peace in the world' as conceived by the Universal Declaration of Human Rights.

\footnotetext{
${ }^{1}$ Research fellow, University of Szeged
} 